\title{
Forts and fortifications in Wallacea
}

\author{
Sue 0'Connor, Andrew McWilliam and Sally Brockwell
}

\section{Introduction}

This volume documents a common phenomenon found throughout the islands of Wallacea, east of the Wallace Line in the Indonesian archipelago: the fortified hilltop settlement. Historically, fortified settlements have been a common built form across the archipelago. The great naturalist Alfred Wallace (1869), during his survey of the region between 1854 and 1862, and later Henry Forbes (1885) in the mid-1880s, made frequent references to these structures that were in wide use due to the continuing prevalence of hostilities across the region. In the century and more since these records however, the provenance and forms of these remarkable built structures have been largely overlooked by contemporary researchers, and many of these impressive structures are now subject to neglect and erosion, reclaimed by forest regrowth, or repurposed for contemporary construction needs. One possible reason for the scant research attention paid to fortified settlements is their low archaeological visibility and remoteness from contemporary settlements.

The present volume seeks to redress this gap in the record by presenting a selection of research papers on the archaeology and ethnohistory of fortified settlements across the archipelagic region known as Wallacea, offering new perspectives on their origins and purpose, structural forms and defining features. Given the scale and extent of fortifications found in varying degrees of integrity across the island chains from Bali to Maluku and Sulawesi to West Papua, the current collection represents a preliminary set of findings and observations that can form the basis for further investigations and more sustained heritage considerations.

In discussing the concept of 'fortified settlements', we are referring in the main to strategically located, piled stone structures within a broadly similar set of constituent and locational characteristics (see Lape 2006). Most of the fortified settlements we have observed are located in inaccessible places: on hilltops or cliff sites with precipitous drop-offs on one or more sides and masked by dense vegetation. Sections of the forts typically feature massive stone walls up to $4 \mathrm{~m}$ high and $1 \mathrm{~m}$ thick, which demarcate the defensive perimeters of the structures. From an archaeological perspective, these steeply incised crags look uninviting for human habitation, and lack in situ water sources and arable land where crops might be cultivated. In other places, the sites of former fortified settlements are located close to contemporary villages or within seasonal swidden farmland, and many have had their stone walls extensively quarried for use in house foundations, base material for roads or as garden perimeter walls against feral pig incursions. In some cases, only vestiges of the defensive walls remain with scatters of earthenware sherds or porcelain tradeware attesting to their earlier occupation. 
Some of the settlements we discuss in this volume have been occupied in living memory and have rich oral histories recalling their mythic and historical significance. They form important material markers of ancestral origins and renown for the contemporary descendants of these earlier settlers. As the ancestral dwellings of a contemporary lineage they often house the graves of ancestors and other significant focal structures, reinforcing their status as places of veneration that are visited regularly and where sacrificial ceremonies are performed.

The present collection draws on a series of surveys undertaken to prospective locations in the islands of eastern Indonesia. They include surveys undertaken since 2000 by Pannell, O'Connor, McWilliam, Brockwell, Lape and Chao in Timor-Leste; Bulbeck, Caldwell, Hasanuddin and Somba in Sulawesi; Brockwell, O'Connor and Tanidjuro in Sumba; and O'Connor and Kealy in Kisar Island. There are many other prospective locations and island sites where fortification was prevalent. Forbes' (1885) account indicates that they extended as far east as Tanimbar Island (Timor Laut) in southern Maluku, but further research is likely to dramatically expand their distribution across the region.

To date we have recorded over 30 indigenous fortified sites and excavated six forts in different places in Timor-Leste, while Bulbeck and others have recorded systematically a series of stone forts in Sulawesi. On the island of Sumba, Brockwell and O'Connor visited a range of fortified villages, and recorded the graves, internal features and fortified walls, as did Kealy and O'Connor in Babar and Kisar (Figure 1.1). But, as in many areas of the region, sensitivities among contemporary descendants of the former residents over ground disturbance, mostly relating to the continuing ancestral and spiritual significance of the sites, precluded the possibility of excavation. The preliminary results of our surveys and excavations on Timor and Sulawesi Islands form the body of research materials for this volume and begin the process of more systematic documentation into the distribution and variability of fortified locations throughout the archipelago.

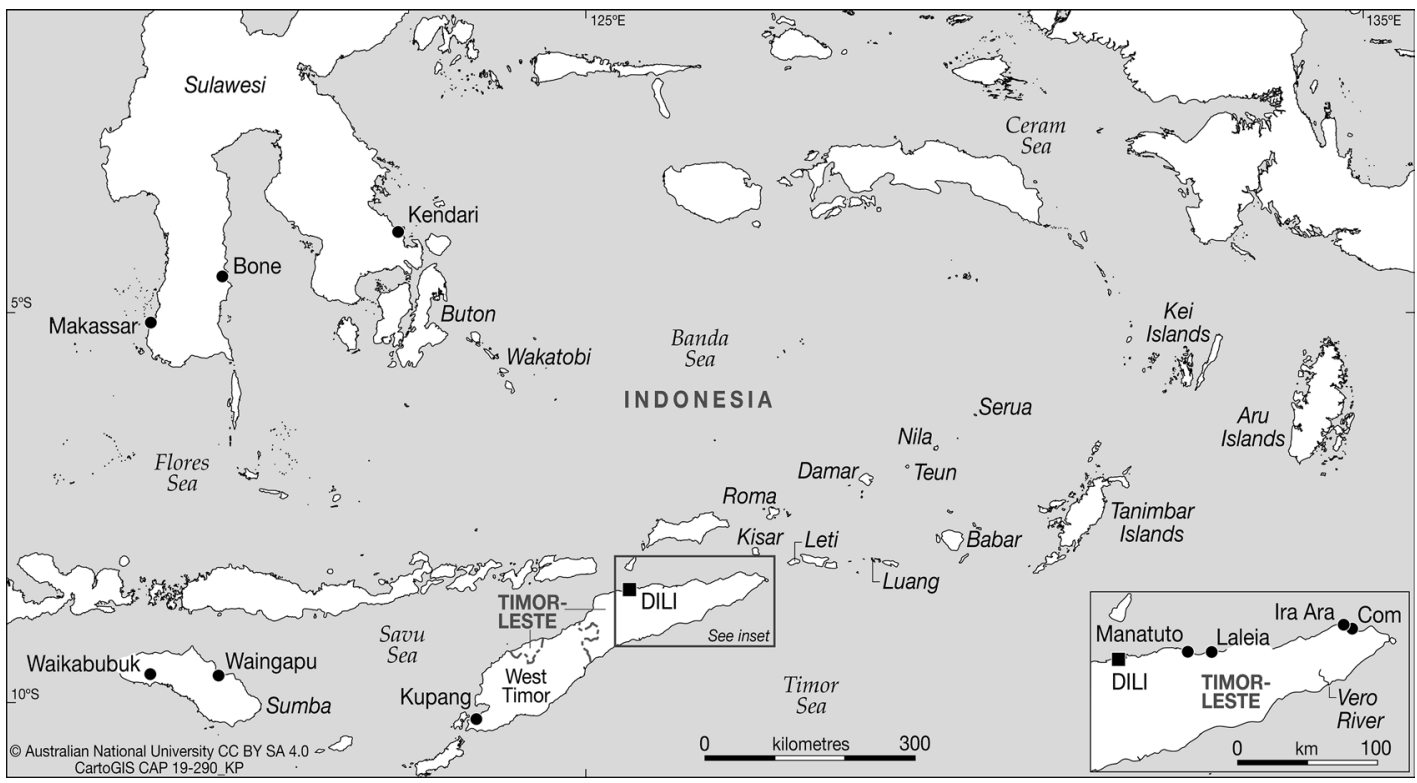

Figure 1.1. Map of study area.

Source: CartogIS ANU. 


\section{Defining fortification in Wallacea}

During his travels in Portuguese Timor during the 1880s, the redoubtable British naturalist Henry Forbes undertook journeys into the interior of the island with a view to collecting plant specimens for scientific documentation. Travelling in a cavalcade of Timorese ponies laden with stores, he made several observations about the people and lands he engaged with, which speak to the unsettled political climate of the time.

From our elevated position the whole country within the sweep of the eye was of a most singular conformation being entirely composed of knife-edges, peaks and precipitous slopes of deep valleys. It surprised me to observe that it was the most inaccessible peaks and isolated crags that were crowned by dwellings, hidden from sight generally among groves of trees. It was easy to see that I was travelling in a lawless land where every man's hand was against his neighbour and where therefore every man was constantly and restlessly on the outlook. (1885:432)

Later he visited the residence of a local headman (Dato) whose camp (Figure 1.2) was located in a strategic, defensive site:

Entering through a high-barred gateway, we found the homestead to consist of eight to ten well built houses ... Surrounded by a high stone wall surmounted by a cactus hedge and built on a rocky buttress jutting out over a precipitous gorge. It was unapproachable except on the one side by which we entered. (1885:434)

Forbes's description applied to the upland territory of Lequidoi in the Mambai-speaking district of Ailieu, but it highlights two common features of Portuguese Timor at the time: namely, the instability and threats of armed attacks by rivals, and equally the prevalence of strategic, fortified settlements located on precipitous cliffs and hilltops. Defensive fortified settlements, it seems, was the preferred and prevailing pattern of residence across much of rural Portuguese Timor.

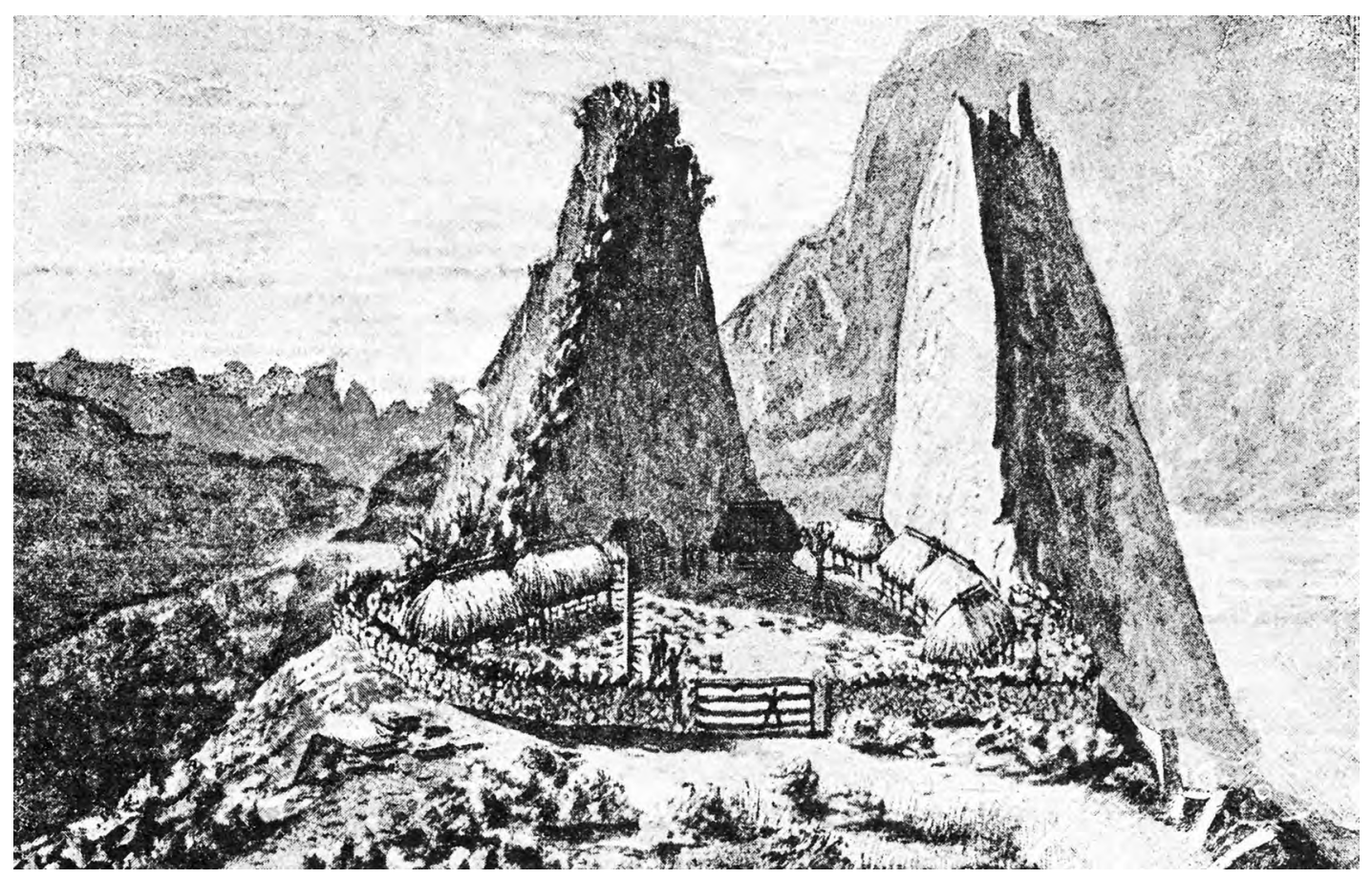

Figure 1.2. The stronghold of Sauo.

Source: H.0. Forbes (1885: facing 434). 
The Dutch geographer F.J. Ormeling, in his 1956 volume on the geography of Timor, also made specific mention of the existence of fortified settlements. He noted that rocky outcrops and hilltops 'provide[d] a natural refuge for the mountain folk. There the people build their fortified mountain villages; there they lay in wait for the enemy' (1956:35). There is a strong continuity here with the description of Henry Forbes.

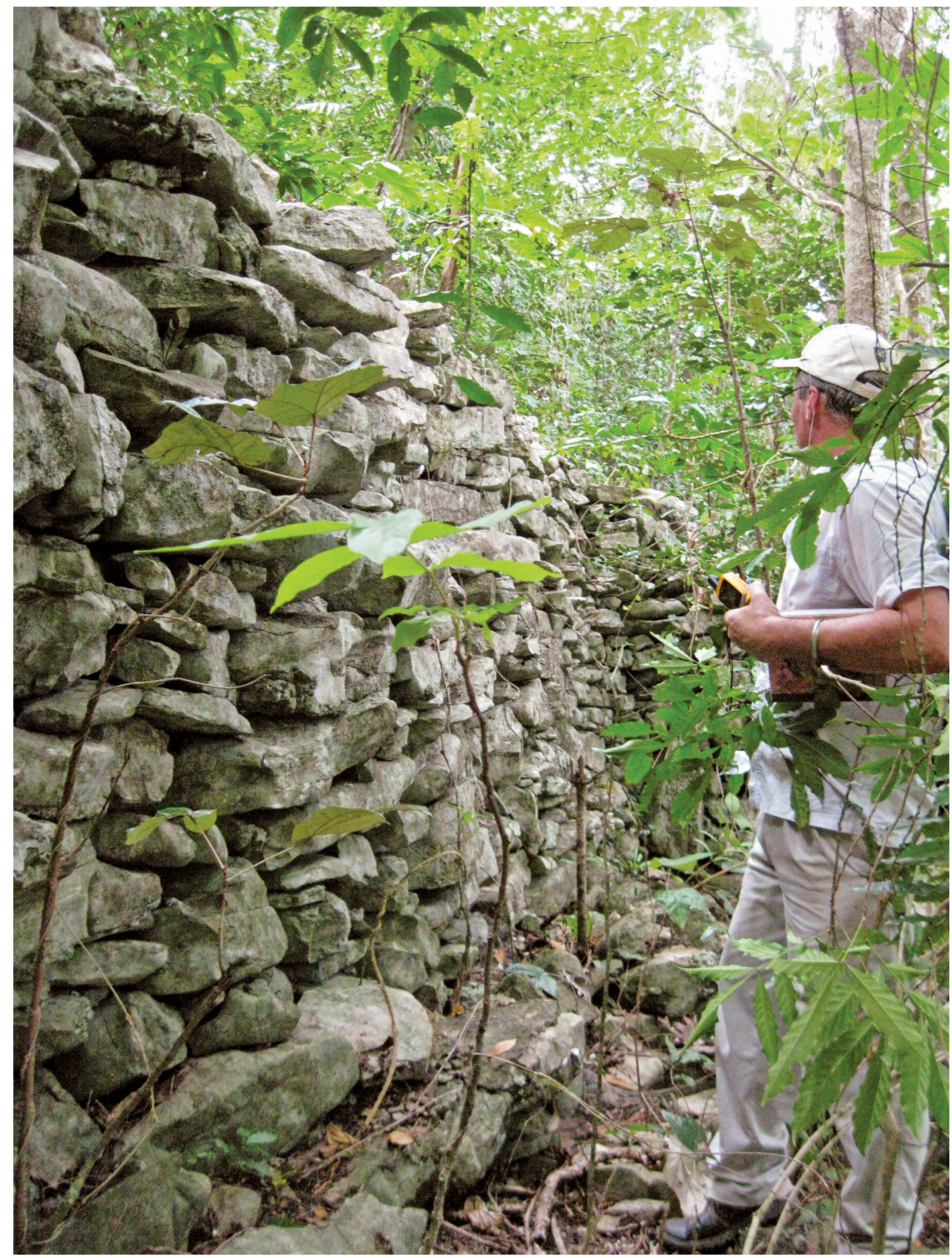

Figure 1.3. Massive limestone rubble walls, Vero Valley, with Andrew McWilliam.

Source: Photo courtesy of Sue $0^{\prime}$ Connor. 
Many of the fortified sites identified in Timor-Leste exhibit several common characteristics, taking into account variations created by site topography and terrain. Forts with more massive walls usually have gateways and narrow meandering passageways, through which people entering were required to pass. In our surveys, the only well-preserved examples of these gateways were located in forested areas well away from contemporary settlements and had avoided the pattern of stone recycling due to their distance away from population centres (Figure 1.3).

Access to the fortified sites may have been guarded from above. The walls on the larger structures are sometimes slitted, indicating that weaponry was probably used to guard the entrances. The thickness of the walls, which are constructed as parallel dry stone ramparts and filled with the coralline rubble that litters much of the landscape of far eastern Timor, suggests that the occupants were defending themselves from more than just spears or even muskets. In the case of the latter, wooden palisades or simple barriers may have sufficed. The massive density of some of the walls suggests that they were built as defence against artillery (cannon) attack, which has also been indicated by oral narratives recorded from local custodians of the sites (see Chapter 6 , this volume). An additional element of the stone walls that assisted in their protective strength was the extensive planting of cacti outside, atop and inside the perimeter walls, providing an additional defensive barrier (see McWilliam 2000:465).

In Timor-Leste, gateways to fortified sites typically open onto an internal walled space (in Fataluku: laca), which is said to be the area where visitors were inspected or greeted. These spaces are often shaped in a semicircular format. Oral accounts, together with the mapping of the internal features of the fortifications, indicate that the settlements also contained circumscribed ceremonial spaces where dancing and communal feasting took place (F: sepu) and areas where ancestral graves are now located.

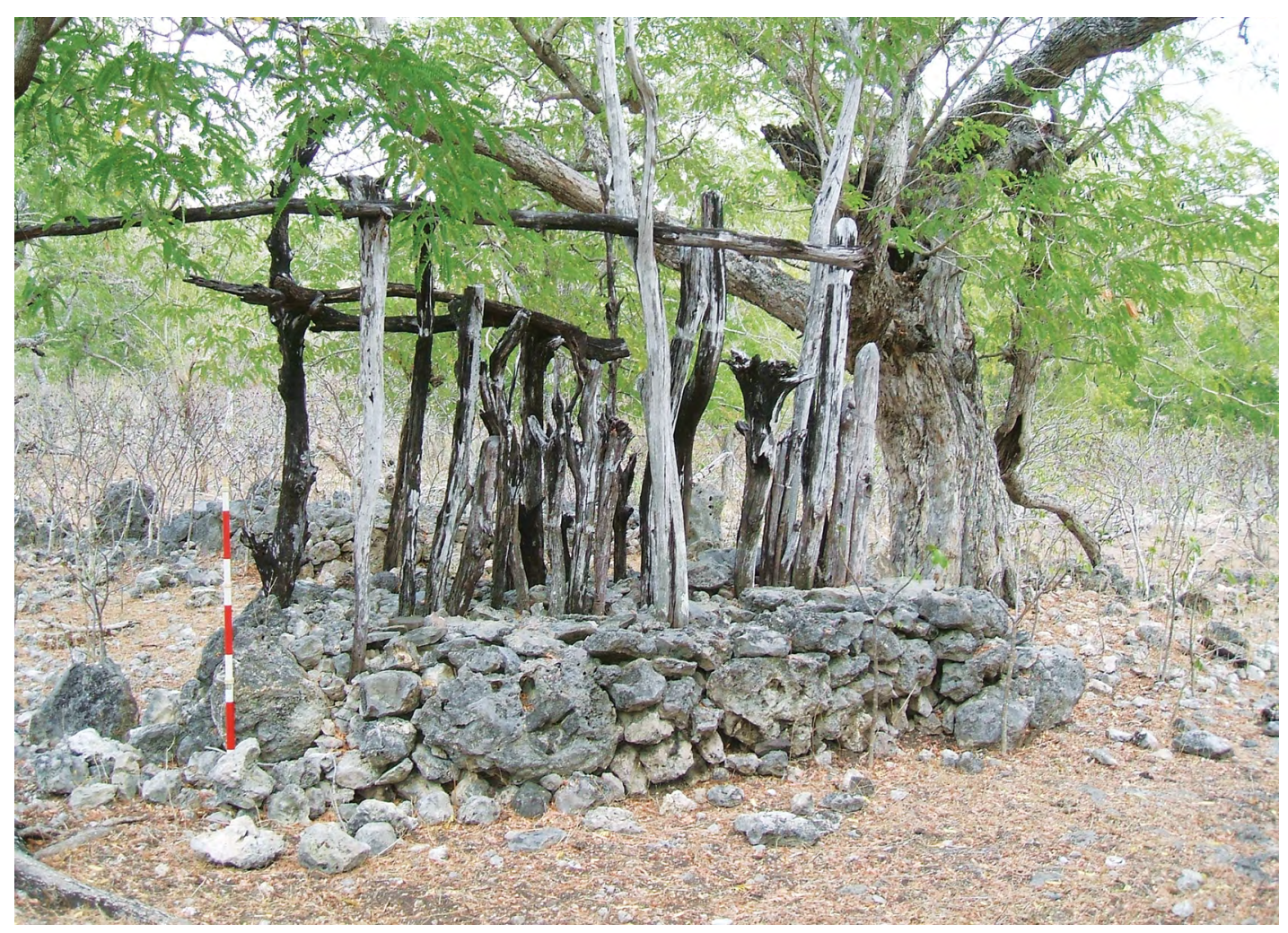

Figure 1.4. Grave and sacrificial platform at Masui.

Source: Photo courtesy of Andrew McWilliam. 


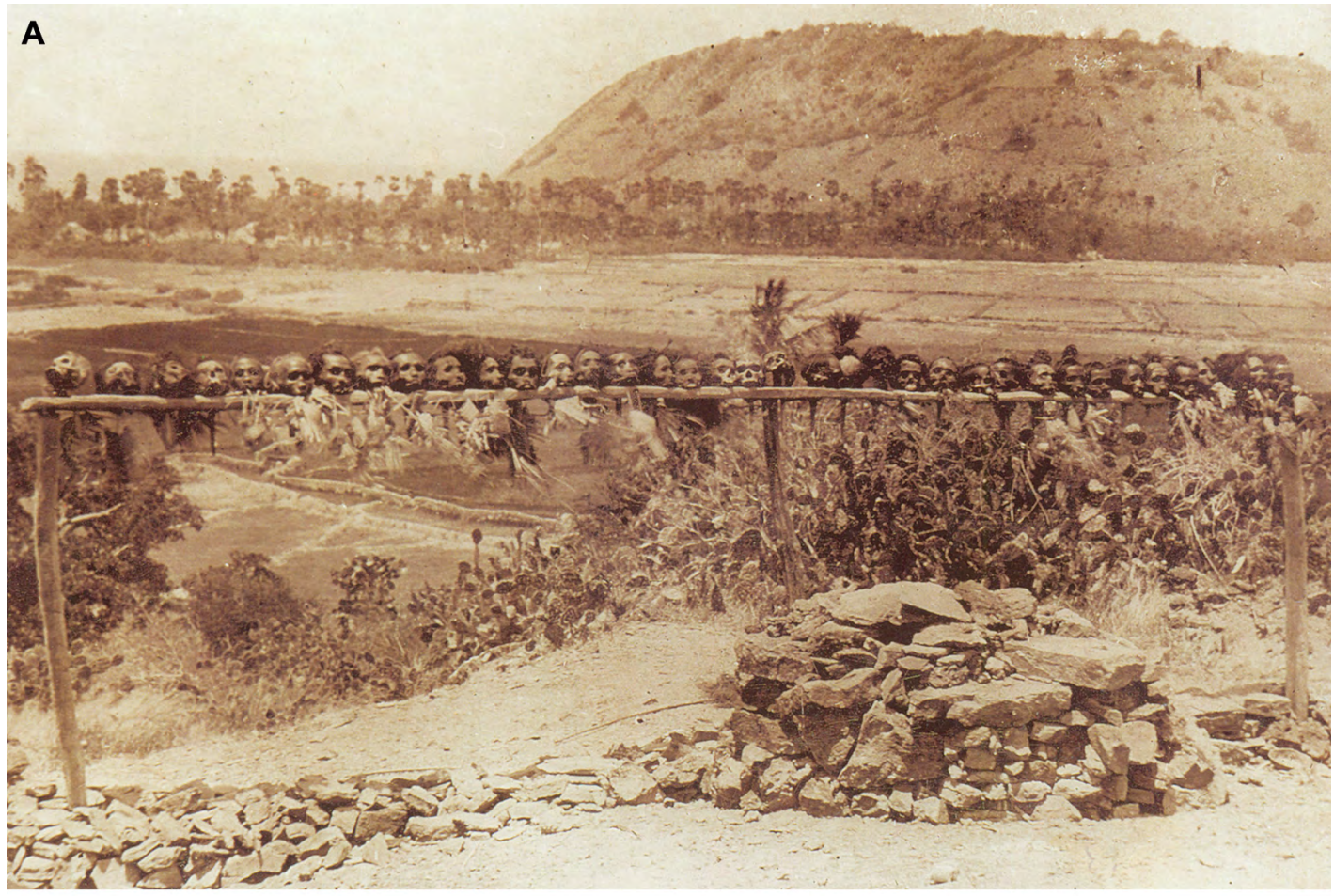

B

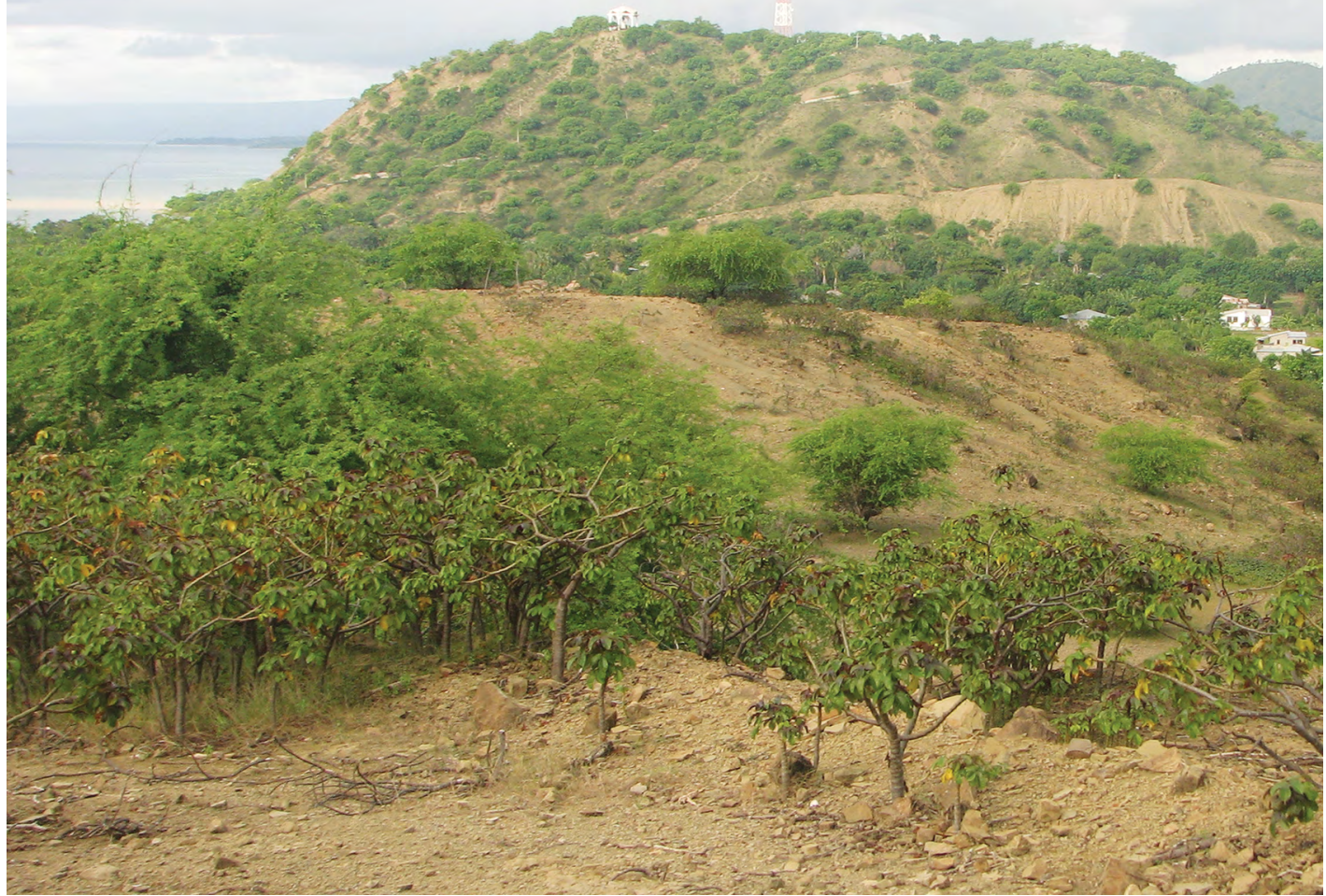

Figure 1.5. Manatuto.

A (above): Skulls on platform looking towards Mt St Antonio with stone altar in foreground, 1913. B (below): Modern-day view of Mt St Antonio with telecommunications tower.

Source: Photo A by António Nascimento Leitão, courtesy of Natural History and Science Museum of University of Porto, register number MHNC-UP-FCUP-IA-AF-775. Photo B courtesy of Sue O'Connor. 
Many forts also include distinctive sacrificial stone platforms and/or altar stones, some of which are marked with standing stones or carved wooden posts (F: ete uru ha'a and or sikua) (Figure 1.4). Like ancestor graves these structures remain highly significant sites of sacrificial veneration for customary owners of the former settlements and are carefully avoided unless ritual activities are intended.

Our survey of a hilltop settlement within the perimeter of the current town of Manatuto indicates that at least some of these platforms were previously used in headhunting rituals (Figure 1.5). Today there is little to be seen on the site of the former settlement; however, our guide noted that, several years prior to our visit in 2010, he had seen a stone 'altar' with human skulls lying scattered around its base. The location where he found the altar is clearly the same spot as that in the 1913 Portuguese photograph in Figure 1.5. This figure reveals more than 30 skulls lined up on a wooden frame above a stone platform (note also the cactus growing on the perimeter of the upper hilltop). The image likely records the success of punitive raids against rebellious Timorese groups in the interior, possibly during or associated with the last great rebellion against Portuguese rule in Timor, the war of Manufahi and the ruler Boaventura (1911-1912), in which Manatuto participants acted as loyal militias and reservists (arrarais and moradores) for their colonial Portuguese allies (see Roque 2010). As the photo was taken in 1913, this festival of heads (Festival das Cabeças) clearly represents a Portuguese-sanctioned activity - so not directly related to the origins of fortification but evidence that inter-communal violence was common until the early twentieth century. Today in this location there are small stone houses with stone bases, walled yards and gardens, which have no doubt recycled the stone from the platform and walls of the fortified settlement of Sau Huhun at Manatuto (see Chapter 11).

According to oral accounts, residential and ritual houses were built within the walls of the fortified dwellings, and historical records indicate that they were in the style of elevated, four-posted structures consistent with the classic Austronesian built designs (see Hauser-Schaublin 1989:13). Oral traditions also indicate that gardening and other subsistence-related activities took place outside the walls on the lower slopes, while domestic animals, such as cattle and buffalo, would be herded into the enclosures in times of threat or imminent attack. Surprisingly, all fortified sites that we have recorded lie some distance from freshwater sources, with nearest springs or creeks sometimes being kilometres distant.

\section{Why were settlements fortified?}

Decisions to construct defensive fortifications against the threat of attack and violent conflict have been a recurring feature of human settlements from earliest antiquity. The reasons and proximate causes that precipitate and sustain fortification, however, have long been the subject of debate and speculation. Among the array of reasons put forward include struggles over limited resources, the desire to control strategic locations, or a response to repeated incursions or invasion by foreign forces.

Archaeologists have somewhat conflicting views regarding the drivers of fortification. Lape and Chao (2008; cf. also Field 2008) have linked the emergence of fortifications in the Indo-Pacific region with a period of rapid climate change, reduced rainfall and environmental fluctuations beginning about AD 1000, leading to resource unpredictability and inter-group conflict driven by competition for fertile land and resources. These arguments are reviewed in detail in this volume by Bulbeck and Caldwell (Chapter 7). On the other hand, O'Connor et al. (2012) have argued that where such structures have been reliably dated in Island Southeast Asia, it has been shown that most were constructed well after this period, with a peak of fort building occurring in the fifteenth to seventeenth centuries $\mathrm{AD}$; much later than the climate change model would allow. Instead, they suggest that the late onset of fortification, coupled with 
findings from anthropological and historical research, indicates that a range of external social and economic factors may have been more significant catalysts for the onset of fort-building (see also Chapter 6, this volume). McWilliam (Chapter 6, this volume) discusses the trade in sandalwood from the island of Timor, and how exchanging sandalwood for value goods, such as iron, ceramics and later muskets and gunpowder, must have led to inequalities in wealth. The introduction of maize and the expansion of wet rice (sawah) cultivation at the time of Dutch and Portuguese colonisation may have allowed for new levels of agricultural productivity, supporting higher population densities and more opportunities for surplus production and its control. The regional trade in slaves may also have played a significant role, particularly in the seventeenth and eighteenth centuries $\mathrm{AD}$, corresponding with the rise in Dutch colonial demand for labour in places like the nutmeg plantations on Banda Island in neighbouring Maluku. Slaves were often acquired as a result of inter-polity raiding, and this may in turn have accelerated the process of fortification and alliance. Populations without physical, geographical or warrior protection would have been particularly vulnerable to raiding parties.

\section{Kingdoms, princedoms, chiefdoms?}

Historical sources are also far from unanimous about the scale and complexity of autonomous rule that should be ascribed to the polities in the different islands of Wallacea, or even within single islands. Hägerdal (2012:52), for example, points out that the Dutch and Portuguese sources of the seventeenth and early eighteenth centuries use the term kings (reis, koningen) to describe the local leaders, and kingdoms (reinos, rijken) to describe the areas they ruled. He argues this translation of the local concepts has exaggerated their importance, given the size of the local domains and the overall population of Timor at the time. He also points out that there were significant variations in the size and complexity of the diverse autonomous domains across the islands. The ruling domains in Java, South Sulawesi and parts of Sumatra, for example, could be as large as, and comparable in terms of population and control of goods with, European kingdoms. Conversely, hereditary rulers of political jurisdictions on islands such as Rote and Sawu were basically 'lords' of a mere few villages (Hägerdal 2012:52). For Timor, inconsistency in the sources makes it difficult to estimate the size of these autonomous domains, but overall the impression is of 'a complex of small and steadily shifting centres of power that become increasingly fragmentary the further east one goes' (Hägerdal 2012:52).

The term 'chiefdom' is arguably a more fitting concept to describe the polities represented by the remains of many of the fortified structures. The anthropologist Schulte Nordholt's (1971:403) accounts of West Timor demonstrate the importance of hereditary networks, ritual and kin relationships and marriage alliances in maintaining and extending the power and influence of rulers and their domains. The records of the Dutch United East India Company (Verenigde Oostindische Compagnie, VOC) for the pre- 1900 period indicate that conflicts over the borders of these small polities were rife and rule was rarely stable (Hägerdal 2012:52). Chiefdoms typically expanded and consolidated through exclusion and incorporation (Earl 1853:281), and McWilliam (1996) has suggested that, in eastern Wallacea, this process was in part achieved by the development of ritualised forms of headhunting, which were common throughout the archipelago and used to assert and maintain political centrality between rivals (McWilliam 1996). The politics of indirect rule pursued for centuries by Dutch and Portuguese colonial power are likely to have played into the dynamics of local domain politics and inter-domain struggles for influence and favour (see also Roque 2010). 


\section{Discussion of the chapters in the volume}

The volume is divided into three parts: Archaeology of Forts, Social History of Forts, and Conclusion and Future Directions.

In Part 1, we report on excavations of coastal and inland fortified and other defensive settlements in: Macapainara near the village of Com, the village of Ira Ara, and Vasino fort near the village of Moro at the eastern end of Timor-Leste (Chapters 2, 3 and 4); and Leki Wakik near the village of Laleia in north central Timor-Leste (Chapter 5) (see Figure 1.1). Chapters 2, 4 and 5 describe the excavation, chronology and analysis of assemblages of shell, animal bone and trade items from Macapainara, Vasino and Leki Wakik, built on steep hills at the eastern end of Timor-Leste, with the aim of establishing a history of settlement and subsistence at these sites. In Chapter 3, Lape et al. describe investigations at nearby Ira Ara, a fortified settlement site with human graves that provides new data on diet, trade and mortuary practices $\mathrm{c}$. $\mathrm{AD} 1700$. The radiocarbon dates and tradeware from these particular settlements in Timor-Leste point to occupation between the fifteenth and mid-twentieth centuries.

Oral accounts and social history relating to the use of the fortified sites in Timor-Leste and southern Sulawesi are discussed in Part 2. In Chapter 6, McWilliam argues against the position proposed by Lape and Chao (2008) that fortification is related to climatic unpredictability and social conflict over access to resources. He draws on a range of historical, ethnographic and archaeological evidence from Timor-Leste to suggest an alternative set of social drivers for processes of fortification. These factors comprise momentous changes in social conditions that coincided with the advent of Portuguese colonialism in the region from the early sixteenth century. Bulbeck and Caldwell support McWilliam's arguments in Chapter 7, where they draw together a wealth of scattered historical and archaeological evidence regarding indigenous fortifications in South Sulawesi and their sociopolitical foundations to test the theories proposed by Lape and Chao (2008) and Field (2008). Chapters 8 and 9 describe fortifications on the islands of Buton and Wakatobi in Southeast Sulawesi. In Chapter 8, Hasanuddin discusses the broader political tensions that led to fortifications in the sixteenth-century kingdom of Buton. In Chapter 9, Nani Somba describes how the development of forts on Wakatobi was triggered by the islands' strategic geographical location for maritime trade and its role as a colony of Buton. In Chapter 10, Schapper discusses fortifications in Maluku province in far east Indonesia. Using evidence from historical records and linguistics, she argues that, contra Lape and Chao (2008) and McWilliam (Chapter 6, this volume), fortified settlement-building cannot be attributed to particular climatic or socioeconomic conditions but is best understood as a cultural feature diffused on a regional level. Chapter 11 in Part 3 contains the results of surveys of fortifications undertaken in Ainaro, central Timor-Leste; Manatuto, north central Timor-Leste; Vero Valley, eastern Timor-Leste; and the eastern Indonesian islands of Sumba, Babar and Kisar. The volume concludes in Chapter 12 with an assessment of future research directions.

\section{References}

Earl, G.W. 1853. The native races of the Indian Archipelago: Papuans. H. Bailliere, London. doi.org/10.5962/ bhl.title.101733.

Field, J.S. 2008. Explaining fortifications in Indo-Pacific prehistory. Archaeology in Oceania 43:1-10. doi.org/10.1002/j.1834-4453.2008.tb00025.x.

Forbes, H.O. 1885. A naturalist's wanderings in the Eastern Archipelago: A narrative of travel and exploration from 1878 to 1883. Sampson, Low, Marston, Searle and Rivington, London. doi.org/10.5962/bhl.title. 36489 . 
Hägerdal, H. 2012. Lords of the land, lords of the sea: Conflict and adaptation in early colonial Timor, 1600-1800. KITLV Press, Leiden. doi.org/10.26530/oapen_408241.

Hauser-Schaublin, B. 1989. Kulthäuser in Nordneuguinea. Abhandlungen und Berichte des Staatlichen, Museums für Volkenkünde Dresden no. 43. Akademie Verlag, Berlin.

Lape, P.V. 2006. Chronology of fortified settlements in East Timor. Journal of Island and Coastal Archaeology 1(2):285-297. doi.org/10.1080/15564890600939409.

Lape, P.V. and C.-Y. Chao 2008. Fortification as a human response to late Holocene climate change in East Timor. Archaeology in Oceania 43(1):11-21. doi.org/10.1002/j.1834-4453.2008.tb00026.x.

McWilliam, A. 1996. Severed heads that germinate the state: History, politics, and headhunting in Southwest Timor. In J. Hoskins (ed.), Headhunting and the social imagination in Southeast Asia, pp. 127-166. Stanford University Press, Stanford.

McWilliam, A. 2000. A plague on your house? Some impacts of Chromolaena odorata on Timorese livelihoods. Human Ecology 28(3):451-469. doi.org/10.1023/A:1007061632588.

O'Connor, S., A. McWilliam, J.N. Fenner and S. Brockwell 2012. Examining the origin of fortifications in East Timor: Social and environmental factors. The Journal of Island and Coastal Archaeology 7(2):200-218. doi.org/10.1080/15564894.2011.619245.

Ormeling, F.J. 1956. The Timor problem: A geographical interpretation of an undeveloped island. T.B. Wolters, Groningen and Jakarta.

Roque, R. 2010. Headhunting and colonialism: Anthropology and the circulation of human skulls in the Portuguese Empire 1870-1930. Palgrave Macmillan, New York.

Schulte Nordholt, H.G. 1971. The political system of the Atoni of Timor. KITLV Verhandelingen 60. Martinus Nijhoff, The Hague. doi.org/10.26530/oapen_613379.

Wallace, A.R. 1869. The Malay archipelago: The land of the orang-utan and the bird of paradise. A narrative of travel with sketches of man and nature. 1st edition. Macmillan, London. doi.org/10.5962/bhl.title. 131886. 
This text is taken from Forts and Fortification in Wallacea: Archaeological and Ethnohistoric Investigations, edited by Sue O'Connor, Andrew McWilliam and Sally Brockwell, published 2020 by ANU Press, The Australian National University, Canberra, Australia.

doi.org/10.22459/TA53.2020.01 